\title{
Costanera Sur: gateway to the Osa - a scenic conservation and development corridor in Costa Rica
}

\author{
T. Gurucharri ${ }^{1} \&$ T. Ankersen ${ }^{2}$ \\ ${ }^{1}$ Department of Landscape Architecture, University of Florida, \\ Gainesville, Florida, USA \\ ${ }^{2}$ College of Law, University of Florida, Gainesville, Florida, USA
}

\begin{abstract}
The concept of scenic landscape protection represents a relatively new approach to conservation and economic development in developing countries. An interdisciplinary and interinstitutional team of professionals in landscape architecture, architecture and environmental law from the University of Florida, University of Costa Rica and the Universidad de Diseño examined the feasibility of a scenic corridor along the economically depressed but ecologically rich southern Pacific Coast of Costa Rica. The Costanera Sur is a 50 kilometer paved highway that offers stunning ocean and mountain views as well as access to Costa Rica's remote Osa peninsula, the largest remaining tropical wilderness on the Pacific Coast of Central America.

The effort gained a sense of urgency due to increasing development pressure and the imminent rerouting of the Pan-American Highway, the major transportation corridor linking North and South America. In addition, access to the beaches for ordinary Costa Ricans has become an increasing concern as foreign investment in exclusive tourism and real estate infrastructure threatens to close off traditional swimming, surfing, picnic and camping areas.

The primary goal of the study was to develop a replicable model for neotropical conservation and development that uses an existing road corridor as the organizing principle for the protection of ecological, cultural, recreational and scenic resources in a developing country where tourism represents the largest source of foreign exchange.

Keywords: scenic corridors, scenic conservation, scenic landscape protection, nature based tourism, sustainable development, resource protection, public recreational access and integrated planning.
\end{abstract}



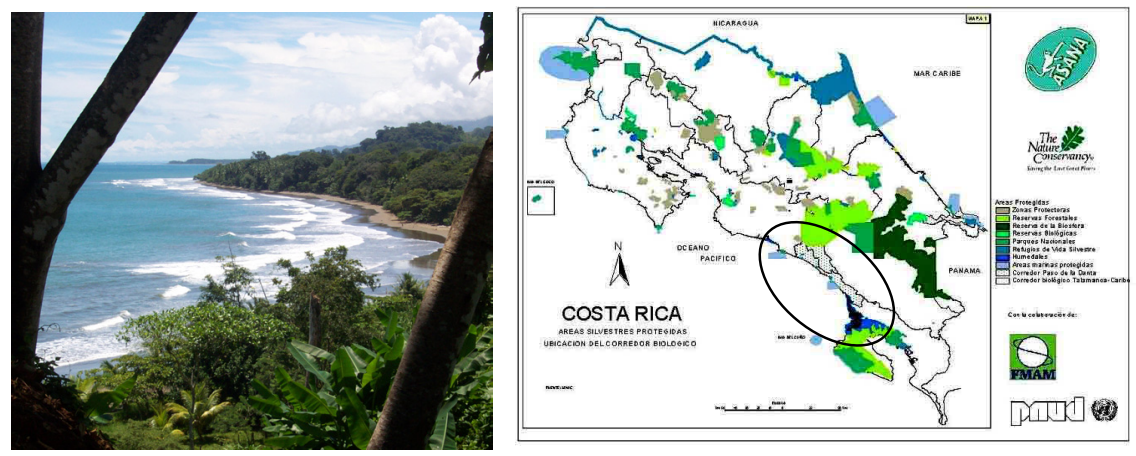

Figure 1: The Costanera Sur and its location between protected areas.

\section{Introduction}

Costa Rica's natural beauty, rich biodiversity, stunning surfing and swimming beaches, as well as peace and stability has attracted many tourists. The central volcanic mountain range, the Cordillera Talamanca, is home to 112 volcanoes and is covered by virgin cloud forests and 500 year-old trees (Hiltunen et al. [1]). From Irazú, one can see on a clear day both the Caribbean and the Pacific Ocean. Although only twice the size of Vermont, it is home to approximately 5\% of all known plant and bird species on earth [2]. Acre for acre, the lowland rain forests supports a greater variety of flora and fauna of any other area on the earth's surface (Hiltunen et al. [1]).

Fortunately, Costa Ricans had the foresight to protect many of these natural resources. One third of Costa Rica is protected in the form of public and private parks and reserves. There are 24 national parks, 125 protected wildlife areas, 10 biological reserves, 12 forest reserves and 34 wildlife refuges (Baker [3]). These natural resource protection initiatives helped fuel their tourism industry. From 1974 to 1994 tourism was third in source of foreign exchange after coffee and bananas. In 1994, it moved into first place (Hiltunen et al. [1]). Growth in the tourism sector continues and is increasingly evident especially along the Pacific and Caribbean coastal regions. Roads continue to provide the primary access to these regions. However, consideration of a scenic highway corridor as an approach to sustainable tourism has received little attention in Costa Rica, or elsewhere in the neotropics.

\section{Corridor theory and the conservation of scenic resources}

The concept of corridors as the basis for landscape level planning has gained considerable currency as an organizing principle for sustainable development (Ankersen [4]). Development theorists also employ the term to describe industrial corridors, including the well-known "Plan Puebla Panama," which posits an interconnected infrastructure corridor that runs from Southern Mexico to Panama. A key element of this proposal is the existing Pan-American 
Highway, the asphalt link between North and South America. More famously, the Central American nations and Mexico joined together in the early 1990s to create the legal and conceptual framework for an isthmian biological corridor to ensure the long-term genetic link between North and South America. In this context, the term has found its way into a variety of international instruments (Ankersen [4]). A key element in Costa Rica's domestic plan to implement the Mesoamerican Biological Corridor is known as the "Paso de la Danta" (Path of the Tapir), the forested corridor through which the Costanera Sur passes [5]. At the same time, a key element in the Plan Puebla Panama asphalt infrastructure is the redirection of the Pan-American Highway to include the Costanera Sur.

In neotropical conservation circles, roads are typically viewed as anathema to conservation (Forman and Sperling [6]). Seldom has consideration been given to the road itself as a conservation resource, an opportunity to operationalize sustainable development along a linear corridor. Scenic conservation offers one such approach, especially when it is tied to a landscape corridor that has been proposed for both development and conservation. The IUCN-World Conservation Union recently added landscapes/seascapes to its list of protected area categories, which it describes as an "area of land, with coast and sea as appropriate, where the interaction of people and nature over time has produced an area of distinct character with significant aesthetic, ecological and/or cultural value, and often with high biological diversity. Safeguarding the integrity of this traditional interaction is vital to the protection, maintenance and evolution of such an area" (IUCN [7]). Costa Rica's Costanera Sur provides the perfect opportunity to test this landscape approach to resource protection.

\section{Costa Rica's Costanera Sur}

The Costanera Sur represents an opportunity to develop a replicable model for the conservation of scenic resources in a developing country, which promotes itself as a leader in sustainable tourism policy. Hugging the southern Pacific coast, the fifty-kilometer asphalt highway offers sweeping views of the both the Pacific Ocean and the cloud crested Fila Costeña Mountains. The viewscape has been favorably compared to California's Big Sur. Although not yet fully developed as a tourism destination, the Costanera Sur has excellent swimming and surfing beaches and opportunities for the development of other nature-based tourism attractions. Just south of the Costanera Sur lies the remote Osa Peninsula and it's crown jewel, Corcovado National Park, the largest remaining tropical wilderness on the Pacific Coast of Central America - and a magnet for nature-based tourism (Ankersen et al. [8]).

Here, many local people continue to depend on resource extraction - fishing, hunting and logging for their livelihood, creating conflicts with on-going conservation initiatives in the region. Recently, more contemporary conflicts have emerged in the form of real estate development and coastal sprawl. Naturebased tourism is viewed as a viable and sustainable economic alternative that would improve the local livelihoods while providing an incentive for local communities to work with conservation initiatives (Honey [9]). As part of 
developing a sustainable economic future for the Costanera Sur, the scenic corridor approach we offer will address these and other social and environmental problems typically associated with development in Costa Rica.

\section{Challenges}

Traditional "sun and fun" tourism, exclusive real estate development, roadside sprawl, illegal squatting, environmental degradation and continued illegal resource extraction, all coupled with the relocation the Pan-American Highway present enormous challenges to efforts that offer the Costanera Sur as a sustainable development model based on the scenic value of a road corridor. In addition to environmental impacts, these challenges create social concerns as well. Exclusive tourism and real estate developments are buying up beach frontage and slowly closing off public access to popular bathing, surfing and camping spots. While technically the beaches remain public, there is no way for the public to get to them (Paniagua and Villalobos [10]). Maintaining traditional access for middle and lower class Costa Ricans to enjoy the natural bounty of their homeland, while providing for tourism and development represents a particularly compelling challenge.

\subsection{Real estate and tourism development pressures}

The rate of growth and nature of new development is quickly and radically changing the character of the Costa Rican coastal landscape. The growth in discretionary wealth among foreign investors coupled with relatively cheap land values is fueling a booming real estate market that is most visible along the coasts. Along the Costanera Sur, the forested view of the Costeña Mountains is slowly being replaced with large houses perched along its slopes, many without architectural regard for the regional context. Beyond the changing viewscape, the effects of the construction are visible from the erosion of newly exposed red clay soil staining the waters of the creeks, rivers and ocean below. A scenic corridor approach must address site-planning strategies for reducing environmental and social impacts from real estate developments and offer design guidelines to ensure a measure of compatibility with the natural and cultural landscape.

\subsection{Roadside sprawl, strip development and illegal squatting}

Costa Rica's population tripled between 1950 and 1985 and continues to grow today at a modest 2.25 percent rate (Hiltunen et al. [1]). While the Costanera Sur remains relatively undeveloped, small-scale urbanizations and creeping highway sprawl have noticeably increased since the tourism boom began in the late 1980s. In the absence of strong planning this trend will continue as the road becomes the de facto service road for both local communities and for through traffic on the Pan-American Highway. Already there are several unsightly strip malls and mega fuel stations. The publicly owned Costa Rican coastal zone has become a flash point for conflict between the government and squatters. The dispute has 
been fueled in part by real estate and tourism developers seeking to "clean up the beaches," but the environmental and social impact of the squatters is real and problematic.

\subsection{Environmental degradation and illegal resource extraction}

Current road development and land development practices do not adequately address their environmental impacts. Stormwater runoff is a particular problem, contributing to streambed erosion and contamination of inland and coastal waters. Poorly sited development exacerbates this phenomenon. After heavy rains, which are frequent in the tropics, the vast amount of water flowing on the surface due to the increased impervious surface, channeled runoff and reduced forest cover causes severe flooding, erosion and water contamination. There is an urgent need to develop strategies for low cost on-site management and treatment of stormwater that can be demonstrated through this project and replicated throughout the country. These considerations, which only recently became a priority in the United States, have not received adequate consideration in national development programs in Costa Rica and elsewhere in the neotropics.

\subsection{Relocated Pan-American Highway}

In many respects the Costanera Sur is a road from nowhere. Clearly constructed to facilitate coastal development, the Cosatanera Sur now provides a crucial link in the effort to relocate the Pan-American Highway along the Pacific coast of Costa Rica. For years, the coastal route to the north of the paved, generouslywide Costanera Sur has been a pothole-filled dirt road with poorly maintained one-lane bridges. This section is now being paved and will also become part of the Pan-American Highway. To the South the road joins the existing PanAmerican Highway at the crossroads to the still remote Osa Peninsula, en route to Panama. Upon completion of the highway project, the Costanera Sur will be an especially scenic section of a high-speed transithmian thoroughfare filled with heavy truck traffic moving goods within the region, and between North and South America.

While the highway project will improve access to the coastal communities and to the Osa Peninsula for locals and tourists, it will also exacerbate current problems the highway creates. These include dangerous road conditions for biking, horseback riding and pedestrians whose communities straddle the road in several places. The incidence of wildlife loss due to roadkill will likely increase exponentially. The character of the landscape will be further degraded due to deficiencies in the design and construction of the highway, especially in areas of severe cut and fill and at bridge crossings. The way the highway has been designed and constructed compromises local transportation needs, and interferes with its viewshed potential. Proper highway design that accounts for its location, scenic qualities, and use as a local transportation corridor is crucial to ensuring that it contributes to the sustainability of the region. Retrofitting this design presents a particular challenge. 


\subsection{Institutional complexity}

The institutional complexity of cross-sectoral coordination required to implement a scenic highway corridor approach represents a special challenge. Current transportation planning in Costa Rica does not offer space for viewshed protection and highway infrastructure oriented to tourism. The cost alone of these "luxuries" is an impediment. During the feasibility study law students and faculty at the University of Costa Rica and University of Florida considered these challenges and concluded that in the absence of national legislation, an inter-institutional agreement between as many as five government agencies would be required. These included the ministries of tourism, the environment, transportation, and housing, along with the municipality of Osa. These institutions demonstrated interest. However, in the absence of an external offer of development assistance from international organizations, they lacked the impetus for coordination.

\section{Solutions: integrated planning based on scenic highway design principles}

These challenges present daunting scenic highway design problems. Ensuring the viability of the Costanera Sur as a scenic conservation and development corridor requires integrated long-term planning coupled with a rational decision making process to ensure the social, visual and ecological protection of the coastal corridor from "ridge to beach." Protecting these resources, and mitigating for current design problems, will ensure that nature-based tourism can be a viable and sustainable economic alternative for the region. Designating the Costanera Sur as a scenic conservation and development corridor would focus attention on a unified vision for the region, and establish an important precedent for neotropical coastal highway development.

To develop the conceptual basis for this feasibility initiative, we assembled an interdisciplinary and inter-institutional planning and design team. The team included architecture and landscape architecture professors from the Universidad de Diseño and the University of Florida, and law professors and students from the University of Florida and the Universidad de Costa Rica. The team considered different methodologies including the complex Context Sensitive Design (CSD) approach developed by the U.S. Federal Highway Administration for scenic highways in the United States [11]. CSD is a "collaborative, interdisciplinary approach that involves all stakeholders to develop a transportation facility that fits its physical setting and preserves scenic, aesthetic, historic and environmental resources, while maintaining safety and mobility" (Myers [12]). The Paris-Lexington Road project in Kentucky, USA is touted as a model of the CSD process (Schneider [13]). 


\section{Why a scenic highway?}

Scenic highways, common in developed countries, are sited in areas that have exceptional scenic value, coupled with one or more special ecological, recreational, historical, cultural or archeological resources. The Costanera Sur certainly qualifies. Moreover, it would be the first "official" scenic highway in Costa Rica, and among the first in Latin America. The Costanera Sur Scenic Highway (carretera panorámica) would offer the opportunity to promote the region as a thematically unified travel route that encompasses a spectacular viewshed, rich ecological resources, unique cultural attributes, and great swimming and surfing beaches for all to enjoy. A protected landscape designation would enhance the Costanera Sur's reputation as the "Gateway to the Osa Peninusula." In turn, properly scaled environmentally friendly tourism could contribute to a more sustainable way of life for the local communities while protecting these valued resources. In modifying the design of the existing road and right of way to conform to principles of scenic highway designation, the project would need to address mitigation measures for multi-modal capacity, improved bridge design for enhanced wildlife and pedestrian crossings, traffic calming features in communities, streetscape design guidelines, stormwater management, viewshed protection and recreational access to beaches and other national resources for both domestic and international tourists.

Since the Costanera Sur represents an existing road alignment within a fixed right of way, there is limited opportunity to incorporate continuous flowing curve alignment ideal for sequenced views (Myers [12]). Any mitigation for aesthetic considerations would still be required to meet the needs for a modern highway geometry designed for heavy trucks traveling at high speeds.

\subsection{Economic benefits of scenic corridors}

Scenic highways can provide economic benefits from both tourism and recreation. Although there are no statistical data to rely on, anecdotally, scenic roads can contribute significantly to a region's economy. Some of the better known scenic roads, the Blue Ridge Parkway in the U.S. Appalachian Mountains and Canada's Yellowhead Route (Western Canada's Scenic Route), are believed to contribute hundreds of millions of dollars annually to their region's economy [11]. By marketing the road as a resource, entrepreneurs along the road benefit, and a multiplier effect spins off regional economic benefits. Good planning is important because as in England's "leisure road" program, it has been so successful that they are grappling with restrictive criteria to maintain an appropriate "carrying capacity" so as to not compromise the resources and keep the number of visitors in balance with its infrastructure capacity [11].

\subsection{Improved multimodal and inter-community access}

Proper design considerations along The Costanera Sur Highway would improve access to all the local communities along the corridor as well as to the remote Osa Peninsula. Currently in Costa Rica little design consideration is given to the 
use of roads by any form of transport other than vehicles. Yet throughout the country roads are crowded with pedestrians, bicycles and even horses competing with vehicles for space - an inherently dangerous situation that manifests itself in graphic accident photos on the front page of newspapers. Pedestrian access along the Costanera Sur would be improved between the communities by proposing a redesigned highway to include a "multi-modal" road that includes safety aspects such as in-road bike lanes, pedestrian and horse trails separate from the road and pedestrian crossings providing residents and visitors safer travel routes.

In addition to benefiting local communities, this improved infrastructure would facilitate new tourism opportunities by providing nodal access to special places with enhanced bike and horse trails. The Costanera Sur region with its rugged but accessible topography, swift rivers with rapids and waterfalls and point of access to the nearby Osa Peninsula already attracts adventure tourists, in addition to traditional "sun and fun" beachgoers. Biking tourism is just beginning to develop in Costa Rica, most of it off road. A safe paved road facility targeted to bikers could open a tourism niche that has great promise. To highlight this, the authors proposed an annual bicycling event to attract both racers and riders from throughout the country.

\subsection{Scenic quality protection}

The Costanera Sur Scenic Highway would offer the opportunity to protect and enhance the corridor's scenic quality by requiring consideration of viewshed protection in developments along the road and especially along the coastal ridge. There is already interesting precedent for scenic quality protection in Costa Rica. Maintenance of scenic quality is specifically identified as an "environmental service" that can be compensated under Costa Rica's novel environmental service payment program (Castro et al. [14]). Moreover, in a recent case in the famed Orosi coffee valley Costa Rica's constitutional court ruled that a municipality must undertake regional planning in response to a petition that claimed that massive fern farm greenhouses were destroying the viewshed that made the valley famous (Castro et al. [14]).

In addition to planning for longer views, a revamped highway design also provides an opportunity to establish a "canopy road," offering shade for pedestrian and vehicular traffic and reducing road fatigue induced by glare and tropical heat. It is important that the roadway planting design be based on existing native vegetation and cultural landscape patterns reflective of the region as a way to visually and ecologically integrate the road way into the adjoining landscape (Schneider [13]).

\subsection{Wildlife crossings by design}

The connected canopies over the road would create safer wildlife crossings for arboreal animals such as monkeys while culverts under the road and larger span bridges would improve safety for other wildlife movement, especially in areas identified as wildlife corridors. A man-made "monkey crossing" on the access 
road to Costa Rica's Manuel Antonio National Park has become a local tourist attraction (ICOET [15]).

Every year, many of the smaller and older bridges are blown out during the rainy season due to the heavy rainfall and increased runoff caused by expanding urbanization and deforestation. Riparian corridors need more protection to ensure an adequate vegetated zone to protect against erosion potential and to enhance wildlife movement. As part of the highway design, improved bridge designs with longer spans would protect infrastructure from the heavy flows, and increase the area beneath the span for wildlife movement along riparian corridors. The bridge design would incorporate pedestrian and bicycle lanes to improve human crossings as well.

\subsection{Maintain access to recreational resources for domestic tourism and local communities}

Currently, there is no mechanism to ensure that beaches historically used for swimming, surfing, camping and picnicking by Costa Rican nationals remain accessible to the public. Foreign investment backed real estate pressures around Costa Rica are slowly eliminating public access to these resources, leading to social unrest in some parts of the country. While Costa Rica has been successful in developing an impressive protected area program at the national level, it has not replicated this for smaller scale public parks and recreation facilities at the provincial and municipal level. Any planning methodology designed to promote sustainable tourism must consider domestic tourism and the recreational needs of local peoples. One approach studied in this project is the development of a new land use category for public beaches and its associated infrastructure. These could be run by a local concessionaire and provide services and maintenance of restrooms, picnic tables, trash receptacles, camping areas, restaurants, and convenience store. A public beach concession concept was explored at Playa Dominicalito near the northern gateway to the Costanera Sur. Playa Domicalito is one of several beaches used not only by local peoples, but also by urban Costa Ricans seeking weekend getaways. Lower budget foreign tourists also take advantage of the opportunities that open access provides. Because it was under imminent threat of "privatization" by a foreign investor selling the concept of a "private beach" to adjacent mountain real estate, we took a closer look at Playa Dominicalito and developed a site plan for a public recreational beach park using principles that could be employed on most any beach to ensure continued availability for access and amenities.

\section{Conclusion: the scenic conservation and development corridor as a new model for sustainable tourism}

The Costanera Sur Scenic Highway initiative could be a model for sustainable coastal tourism development in developing countries threatened by new or improved transportation infrastructure and exclusive foreign investment. We found considerable receptivity to the concept among various institutions and 
actors in the Capitol and in the region. However, the relative novelty of the concept coupled with the economic investment required suggests that there is a long road toward implementation. At the same time, if this approach will work anywhere, Costa Rica and the Costanera Sur offer the best hope.

\section{References}

[1] Hiltunen Biesanz, M., Biesanz, R., and Zubris Biesanz, K., The Ticos: Culture and Social Change in Costa Rica, Lynne Rienner Publishers, Boulder and London, pp. 3-55, 1999.

[2] Deforestation in Costa Rica: A Quantitative Analysis Using Remote Sensing, www.bioone.org

[3] Baker, C. P, Costa Rica Handbook, Moon Travel Books, pp. 23-32, 1999.

[4] Ankersen, Thomas T., The Mesoamerican Biological Corridor: The Legal Framework for a Regional, Integrated System of Protected Areas, 9 Journal of Environmental Law and Litigation 499, 520, 1994.

[5] Paso de la Danta, www.pasodeladanta.org

[6] Forman, Richard T. T. \& Sperling, Dan, Eds., Road Ecology: Science and Solutions, Island Press, Washington, DC, 2003.

[7] IUCN, www.iucn.org/themes/wcpa/pubs/pdfs/iucncategories.pdf

[8] Ankersen, Thomas T., Regan, Kevin E. \& Mack, Steven A., Towards a bioregional approach to tropical forest conservation: Costa Rica's Greater Osa Bioregion, 38 Futures 406-431, May, 2006.

[9] Honey, Martha, Ecotourism and Sustainable Development: Who Owns Paradise? Island Press, Washington, DC, 1999.

[10] Paniagua Alfaro, F. \& Villalobos Molin, L., Manual de la Ley Sobre la Zona Maritimo Terrestre, Editorial de la Universidad de Costa Rica, 1996.

[11] "Scenic Highways and Byways Programs Outside the United States", Final Case Study for the National Scenic Byways Study, U.S. Department of Transportation, Federal Highway Administration, Publication No. FWHA-ED-90-036, pp. 4-5, 1990.

[12] Myers, M. E., The Line of Grace: Principles of Road Aesthetics in the Design of the Blue Ridge Parkway, Landscape Journal. 121-140, pp. 133138, 2004.

[13] Schneider, K., The Paris-Lexington Road: Community Based Planning \& Context Sensitive Highway Design, Island Press, Washington DC, Covelo, California, pp. 42-72, 2003.

[14] Castro, Rene, L. Gámez, N. Olson and F. Tattenbach. The Costa Rican Experience with Market Instruments to Mitigate Climate Change and Conserve Biodiversity. Journal of Environmental Monitoring and Assessment 61: 75-92. Kluwer Academic Publishers. 2000.

[15] ICOET, www.icoet.net/ICOET_2005/05abstract8.asp 